\title{
THE POSSIBILITY TO USE SELECTED MIXTURES OF PGPR BACTERIA IN TOMATO CULTIVATION
}

\author{
Magdalena SZCZECH, Jacek DYŚKO \\ Research Institute of Vegetable Crops \\ Konstytucji 3-Maja 1/3, 96-100 Skierniewice, Poland
}

Received: February 21, 2008; Accepted: June 3, 2008

\begin{abstract}
Summary
Mixtures of different plant growth-promoting rhizobacteria (PGPR) were used to control soil-borne pathogens of tomato plants. First, their effect was studied in mini-chamber tests against Rhizoctonia damping-off. The best strains and their mixtures were selected for the greenhouse and field experiments conducted in years 2006-2007. The seeds and then the roots of tomato transplants were inoculated with the suspensions of single bacterial strains or with their combinations. In the greenhouse experiments treated plants were grown in the potting medium infested with pathogenic Fusarium oxysporum f. sp. lycopersici, and the effect of bacteria on the population of Fusarium spp. in the rhizosphere was studied. In field experiments the plants were planted into natural infested soil. In both kind of the experiments (greenhouse and field) the impact of the inoculation on plant yield and diseases incidence was evaluated. Although, the results of the preliminary and mini-chamber tests were promising, and the bacteria B125, PT42, SZ141 and their mixtures significantly reduced damping-off of tomato seedlings, in greenhouse and field experiments, in most cases the bacterial treatments failed to improve yield and to protect the plants. Among tested bacterial inoculations only the mixture of the bacteria B125 and PT42 tended to affect positively the growth of the plants and to reduce their infection by soil-borne pathogens. However, bacterial inoculations significantly decreased the density of Fusarium spp. in the rhizosphere of tomato plants.
\end{abstract}

key words: bacterial mixtures, biocontrol, damping-off, Fusarium wilt

\section{INTRODUCTION}

The growing public concern of environmental pollution from pesticides has induced researchers to find nature-safe means of plant pathogens control. For several decades various bacteria, named plant growth-promoting bacteria (PGPR), or fungi have been introduced to soil or seeds to improve plant growth and to suppress pathogens. However, single microbial strains have relatively narrow spectrum of activity and their efficacy is often inconsistent. Thus, generally they fail competition with chemicals. It was found that integration of

Corresponding author:

e-mail: mszczech@inwarz.skierniewice.pl

(C) Copyright by RIVC 
several microorganisms may provide more reliable effects in plant protection against pathogens (Fukui et al. 1999, Guetski et al. 2001, Szczech \& Shoda 2004, Spadaro \& Gullino 2005, Szczech 2008). Especially combining of microorganisms exhibiting different modes of action may broaden spectrum of their activity and reduce variability in natural changeable environment (Rapauch \& Kloepper 1998, Guetsky et al. 2002, Jetiyanon \& Kloepper 2002, de Boer et al. 2003, Bennet \& Whipps 2008).

In our studies several strains of PGPR bacteria were chosen as effective agents for biocontrol of plant pathogens. They were preliminary examined for their efficacy in control of soil-borne pathogens of tomato plants, used as single and combined inoculants, and promising results were obtained (Szczech \& Dyki 2007). The aim of the presented work was to study the effect of selected bacterial mixtures on tomato growth under greenhouse conditions, with the potting medium inoculated with pathogenic Fusarium oxysporum f. sp. lycopersici, and in field with naturally infested soil. The effect of bacterial inoculation on the population of Fusarium spp. in the rhizosphere of tomato plants was also studied.

\section{MATERIALS AND METHODS}

The bacterial strains used in the experiments were: PT42, PT60, SZ141 and B125. They were isolated from the rhizosphere of tomato and lettuce and from vermicompost. These bacteria exhibited various mechanisms of biocontrol: antagonism, plant growth promotion and induction of resistance (Szczech \& Dyki 2007). Bacteria were cultured on nutrient agar for 48 hours and then scratched from the surface of the medium and suspended in $0.85 \%$ water solution of $\mathrm{NaCl}$. The density of cells in the inoculum was about $10^{9} \mathrm{cfu} \mathrm{mL} \mathrm{L}^{-1}$. To prepare mixed inoculum, equal volumes of single bacterial suspensions were combined just before application.

Plastic containers (Tigret, Poland) with two divided mini-chambers were used. One mini-chamber was filled with $50 \mathrm{~g}$ of potting medium (Klasmann) inoculated with homogenized mycelium of $R$. solani $(1 \mathrm{~g}$ of the mycelium per $1 \mathrm{~L}$ of the medium). The medium was seeded with 10 seeds of tomato $\mathrm{cv}$. Remiz $F_{1}$. The seeds were treated with $5 \mathrm{~mL}$ of bacterial inoculum. Control seeds were treated with $5 \mathrm{~mL}$ of $\mathrm{NaCl}$ solution. In one set of the experiment suspensions of single and mixed bacterial strains B125 and PT42 were used. In the second one the suspensions of bacteria PT42, PT60, SZ141 and the mixtures PT42+PT60, PT42+SZ141 and PT60+SZ141 were applied to the seeds. Each treatment was replicated three times. The mini-chambers were incubated for 7 days in a growth chamber $\left(25^{\circ} \mathrm{C}, 14\right.$ hours of light, $90 \%$ of humidity $)$ and the number of growing tomato seedlings was estimated. Both sets of the experiment were repeated twice.

For greenhouse experiments tomato seeds were sown into pots $(50 \mathrm{~mL})$ and treated with $5 \mathrm{~mL}$ of the inoculum containing single strains of bacteria B125, PT60, PT42, SZ141 or mixed bacteria B125+PT42, PT42+PT60, PT42+SZ141 and PT60+SZ141. The pots were maintained in a greenhouse. After five weeks the transplants were planted into pots $(7.5 \mathrm{~L})$ filled with com- 
mercial potting medium Klasmann not infested or infested with the propagules of $F$. oxysporum f.sp. lycopersici. Fungal inoculum consisted of spores and fragments of mycelium scratched from the surface of two-week-old fungal culture on $9 \mathrm{~cm}$ Petri plate per $2 \mathrm{~L}$ of the medium. Before planting, roots of the transplants were dipped for $15 \mathrm{~min}$ in the bacterial suspensions, prepared respectively as for seed inoculation. Roots of control transplants were kept in $\mathrm{NaCl}$ solution. Each treatment was replicated three times. Plants were grown in the greenhouse in a randomized blocks. They were watered and fertilized depending on the needs, and were topped over the forth cluster. Fruits were harvested 2-3 times a week and total yield was estimated. After the experiment was completed, the severity of Fusarium wilt was estimated according to a 0-4 disease index: 0 - no disease symptoms; $4-100 \%$ necrosis of the stem base cross section. The density of Fusarium spp. in the rhizosphere of treated tomato plants was studied on Komada's medium (Dhingara \& Sinclair 1995).

The experiments were performed during two consecutive years 2006 and 2007. In the year 2006 tomato plants cv. Dublet $F_{1}$ were used. However, they appeared only little sensitive to the infection by used strain of Fusarium, and the protective effect of bacterial treatments was nullified. Therefore, in the year 2007 a very sensitive to soil-borne diseases tomato cultivar Remiz $F_{1}$ was chosen.

For field experiments tomato transplants, grown from the seeds inoculated with bacteria as it was described above, were planted in a natural sandy loam field soil, containing $2.5 \%$ of the organic matter, under plastic greenhouse. Before planting into ground the roots of the transplants were dipped in the bacterial suspensions. For inoculation following combinations of bacteria were used: B125+PT42, PT42+PT60, PT42+SZ141 and PT60+SZ141. Single inucula were avoided. Roots of control plants were soaked in $\mathrm{NaCl}$ solution. For each treatment four replicates consisted blocks of three plants were prepared (twelve plants for treatment). Plants were grown in rows in a randomized blocks. The distance between rows and plants in the row was 100 and $35 \mathrm{~cm}$ respectively. The plants were watered and fertilized depending on the needs, and were topped over the sixth cluster. Fruits were harvested once a week and total yield was estimated. At the end of the experiment the degree of the development and the severity of soil-borne diseases symptoms on the roots were observed. The root health status was evaluated according to 1-4 index: 1 - root small with strong disease symptoms; 4 - root well developed and healthy.

The results obtained were statistically analyzed with analysis of variance and a significance of differences between means was verified with NewmanKeuls test at the level of significance $\mathrm{P}=0.05$.

\section{RESULTS AND DISCUSSION}

Treating of tomato seeds with PGPR bacteria and especially with the mixtures of bacteria B125+PT42 and PT42+SZ141 significantly decreased Rhizoctonia damping-off in "mini-chamber" tests. The effect of these combinations was better than the results obtained using single components of the mixtures (Fig. $1 \& 2$ ). The good protection of seedlings with these strains of bacteria 
against $R$. solani infection was also obtained in preliminary studies (Szczech \& Dyki 2007; Szczech data not presented). The other mixtures were not active in these tests.

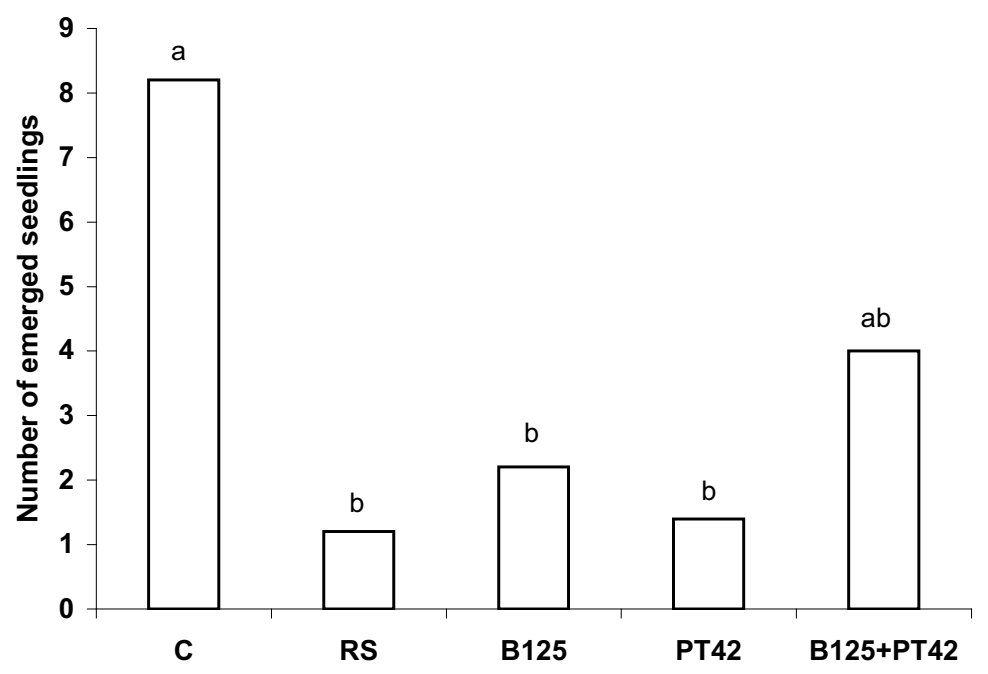

Fig. 1. The degree of Rhizoctonia damping-off severity expressed as a number of emerged tomato seedlings in "mini-chamber" test with bacterial strains B125 and PT42. $\mathrm{C}$ - control treatment without pathogen and bacteria, for other treatments the potting medium infested with $R$. solani (RS) was used. The significance of differences between means was verified with Newman-Keuls test; $\mathrm{P}=0.05$

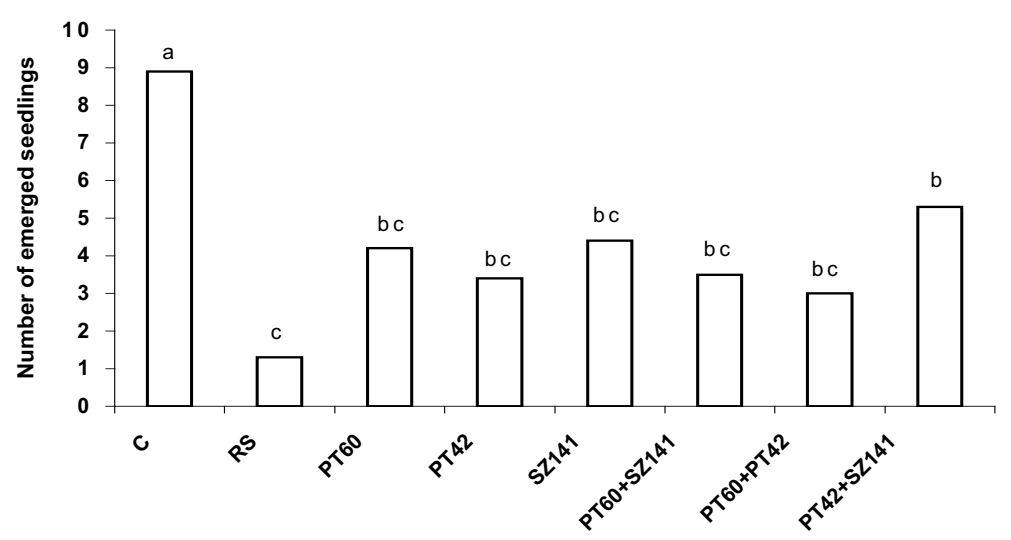

Fig. 2. The degree of Rhizoctonia damping-off severity expressed as a number of emerged tomato seedlings in the second set of "mini-chamber" test with bacterial strains PT60, PT42 and SZ141. C - control treatment without pathogen and bacteria, for other treatments the potting medium infested with $R$. solani (RS) was used. The significance of differences between means was verified with Newman-Keuls test; $\mathrm{P}=0.05$ 
The same combinations of bacteria B125+PT42 and PT42+SZ141, applied to tomato transplants (seed soaking and then root drenching) indicated potential to enhance tomato yield in greenhouse experiments with "healthy" potting medium, not infested with the pathogen (Fig. 3). Although, the differences between control plants and these treated with the mixtures B125+PT42 and PT42+SZ141 were not significant, the positive tendency was visible, especially with tomato cv. Dublet $F_{1}$ (2006). Enhancement of tomato growth was also obtained with a single strain of bacteria B125 (Fig. 3). The other treatments did not affect the plants development and yield. In the medium infested with $F$. oxysporum, the infection of tomato plants in the year 2006 was low (Fig. 5), probably because the plants $\mathrm{cv}$. Dublet $\mathrm{F}_{1}$ were only little sensitive to the pathogen. Therefore, there were not significant differences in total tomato yield between the treatments (Fig. 4). In the year 2007, when the sensitive to soil-borne diseases tomato plants cv. Remiz $\mathrm{F}_{1}$ were used, the Fusarium wilt severity was higher (Fig. 5). However, only single bacteria B125 and the mixture B125+PT42 showed the tendency to decrease the disease. Tomato yield was reduced under strong pressure of the disease, and bacterization of the plants did not affect the yield positively (Fig. 4). The superior control of Fusarium diseases obtained with the mixtures of microorganisms was presented by Park et al. (1988) and De Boer et al. $(1999,2003)$.

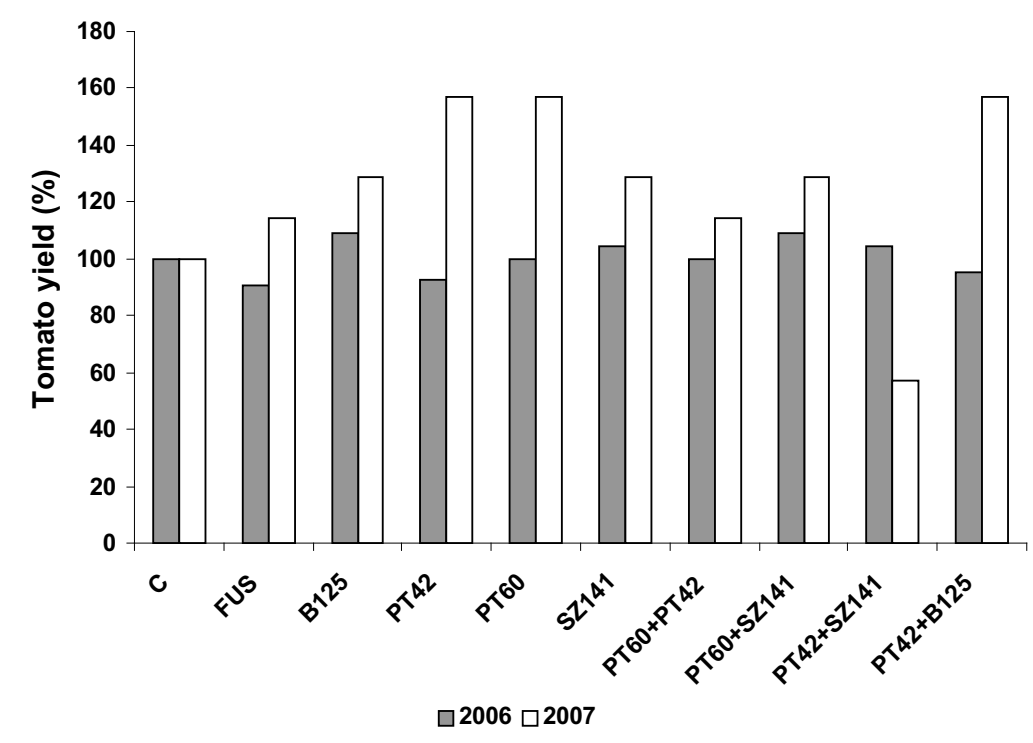

Fig. 3. Total yield of tomato plants grown in greenhouse in potting medium not infested with $F$. oxysporum f. sp. lycopersici. C - control, not infested with the pathogen. In the years 2006, 2007 tomato plants cv. Dublet $F_{1}$ and cv. Remiz $F_{1}$ were cultivated respectively. In both years of the experiment the differences between means were not significant 


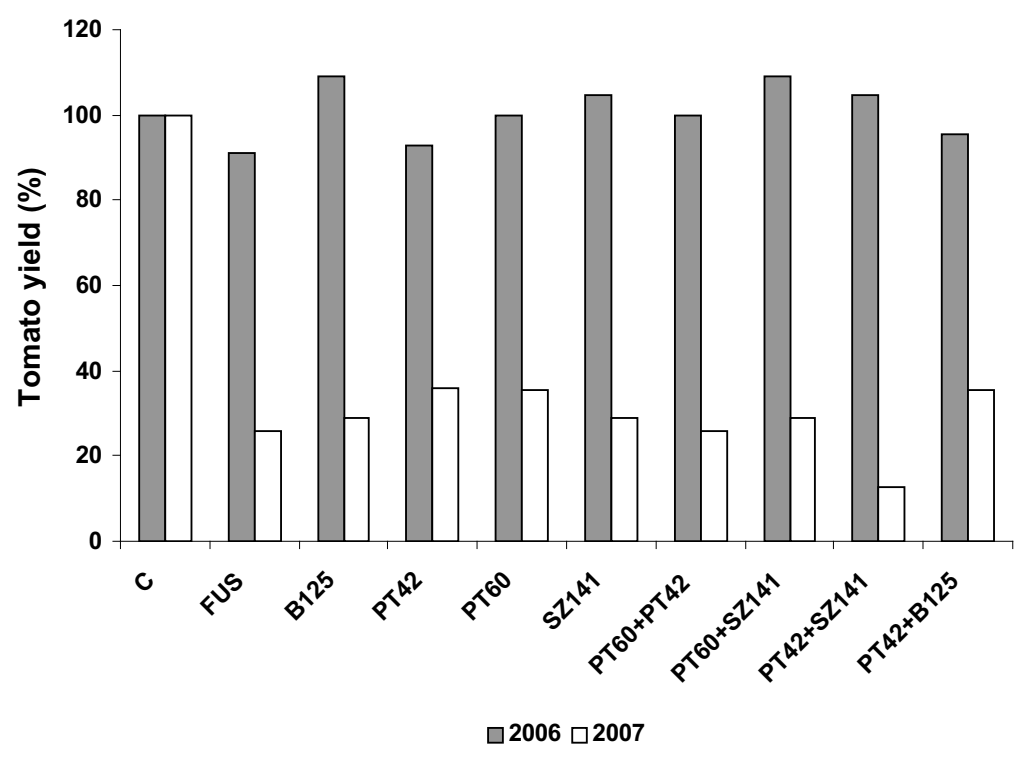

Fig. 4. Total yield of tomato plants grown in greenhouse in potting medium infested with F. oxysporum f. sp. lycopersici (FUS). C - control, not infested with the pathogen. In the years 2006, 2007 tomato plants cv. Dublet $F_{1}$ and cv. Remiz $\mathrm{F}_{1}$ were cultivated respectively. In both years of the experiment the differences between means were not significant

The severity of the wilt was related to the density of the pathogen propagules on the roots of studied plants (Fig. 5, Table 1). From the roots of the susceptible tomato cv. Remiz $\mathrm{F}_{1}$ about 100-times more colonies of Fusarium spp. were isolated than from the roots of tomato cv. Dublet $F_{1}$. However, in the case of both tomato cultivars and in both years of the experiment, it was observed that bacterization generally decreased density of the pathogen in the rhizosphere. This reduction was significant in the year 2007, when disease development was stronger (Table 1). There were differences between treatments: the treatment with single strains of bacteria B125, PT42 and PT60 and with mixtures PT42+PT60, PT60+SZ141 and B125+PT42 significantly decreased Fusarium spp. population, while SZ141 and PT42+SZ141 did not affect the pathogen density in the root zone.

Application of bacteria did not have any clear effect on tomato growth in natural field soil. The yield was not significantly affected regardless of plant cultivar and year of the experiment (Fig. 6). It was only observed in the year 2006 that bacterization significantly stimulated development of roots of tomato plants cv. Dublet $F_{1}$ (Fig. 7). However, this was not obtained in the second year of the experiment with $\mathrm{cv}$. Remiz $\mathrm{F}_{1}$, when a very strong infection of the plants by Pyrenochaeta lycopersici appeared. The symptoms of other diseases on the above-ground parts of the plants and on the roots were not observed. 


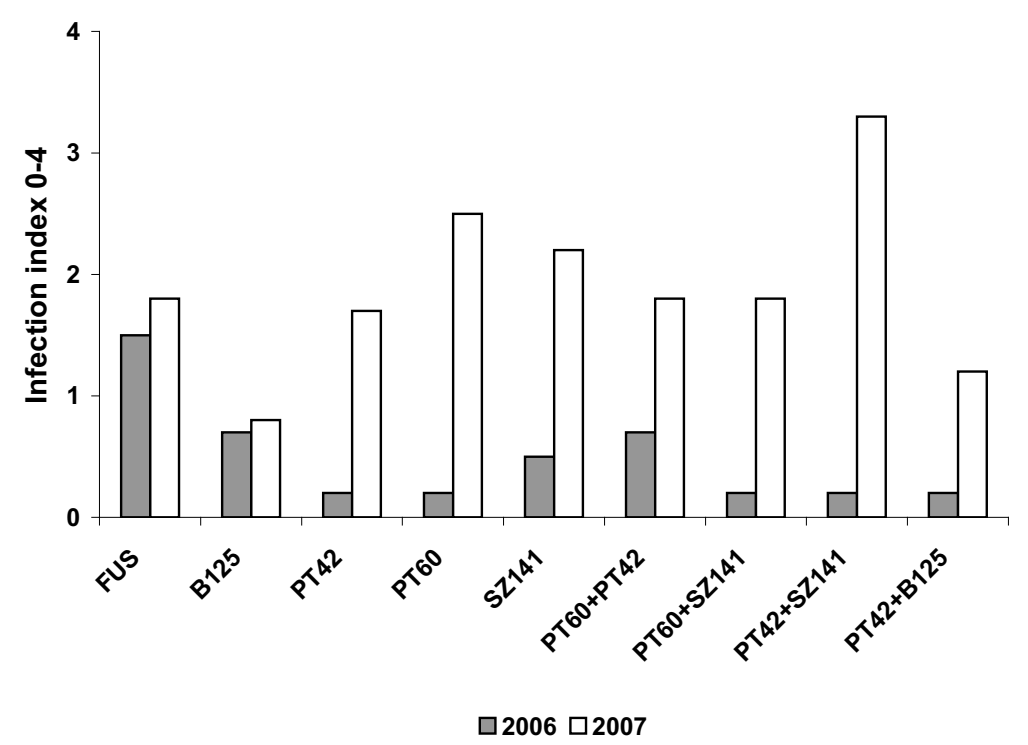

Fig. 5. The severity of Fusarium wilt on tomato plants estimated according to a degree of necrosis of the stem base cross section. FUS - potting medium infested with Fusarium, but plants not treated with bacteria. In the years 2006, 2007 tomato plants cv. Dublet $F_{1}$ and cv. Remiz $F_{1}$ were cultivated respectively. The differences between means were not significant

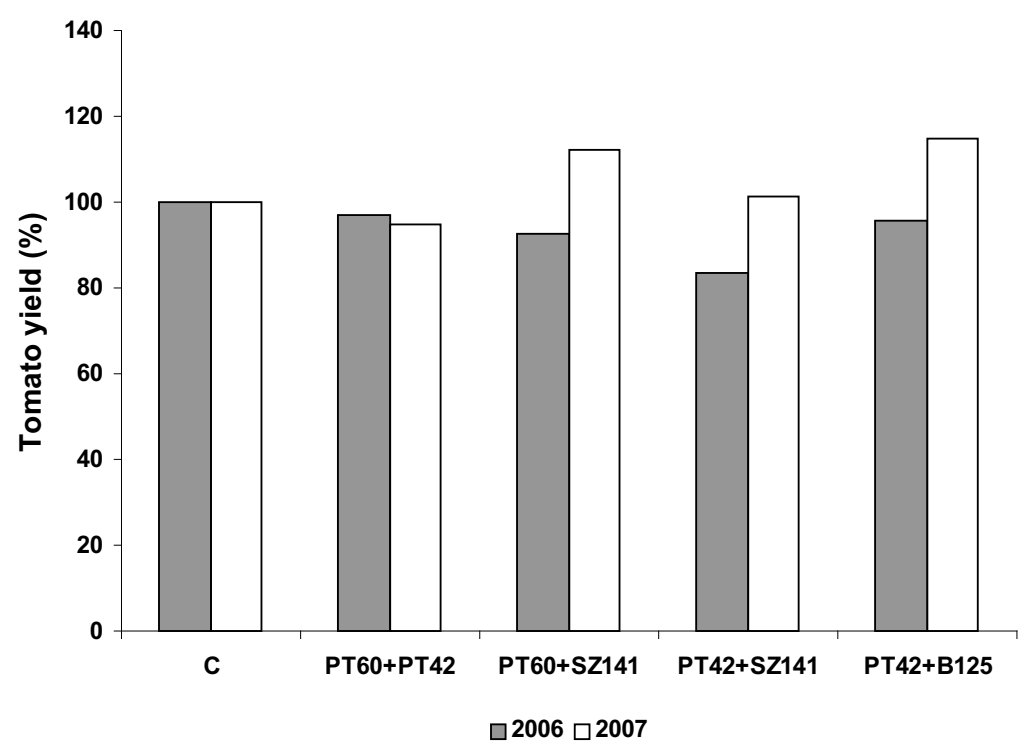

Fig. 6. Total yield of tomato plants grown in field conditions. $\mathrm{C}-$ control. In the years 2006, 2007 tomato plants cv. Dublet $F_{1}$ and cv. Remiz $F_{1}$ were cultivated respectively. In both years of the experiment the differences between means were not significant 


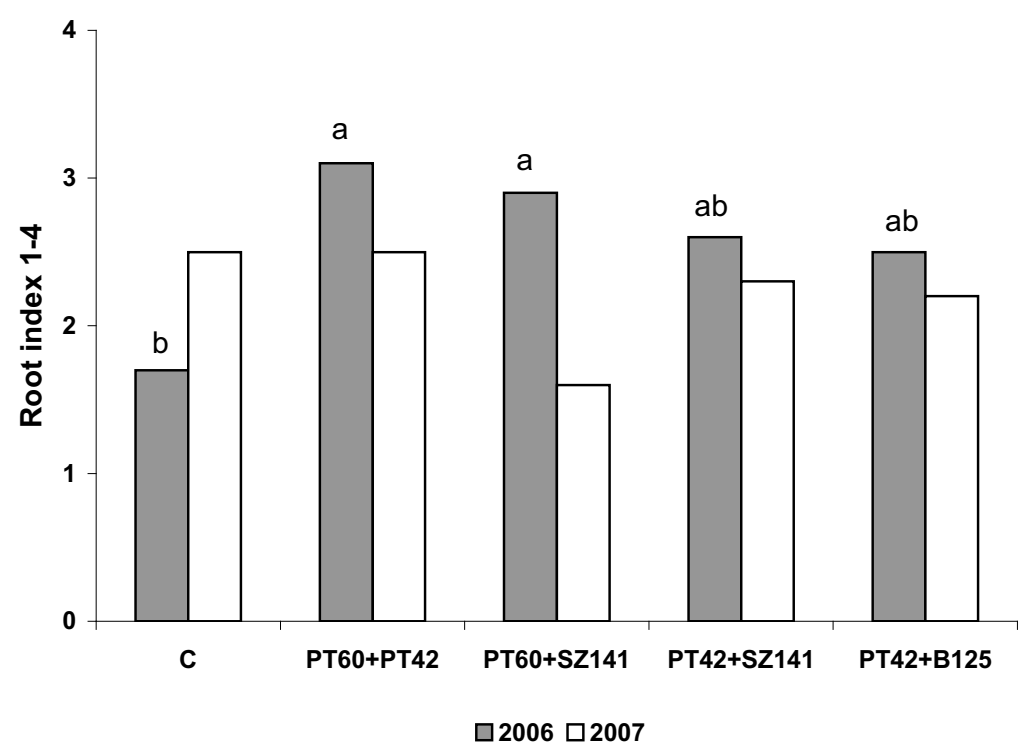

Fig. 7. The root health status of tomato plants grown in field experiments. $\mathrm{C}-$ control. In the years 2006, 2007 tomato plants cv. Dublet $F_{1}$ and cv. Remiz $F_{1}$ were cultivated respectively. The differences between means were significant only in the year 2006 according to Newman-Keuls test; $\mathrm{P}=0.05$

Table 1. The density of Fusarium spp. in the rhizosphere of tomato plants treated with single bacterial strains and with the mixtures

\begin{tabular}{lcc}
\hline \multicolumn{1}{c}{ Treatments } & $\begin{array}{c}\text { Year 2006 } \\
\text { cfu x 10 }\end{array}$ & $\begin{array}{c}\text { Year 2007 } \\
\text { cfu x 10 }\end{array}$ \\
\hline Control with F. oxysporum & 1.5 & $6.1 \mathrm{ab}$ \\
B125 & 2.2 & $0.6 \mathrm{~b}$ \\
PT42 & 0.8 & $2.0 \mathrm{~b}$ \\
PT60 & 0.4 & $3.2 \mathrm{~b}$ \\
SZ141 & 0.5 & $6.1 \mathrm{ab}$ \\
PT60+PT42 & 0.9 & $1.0 \mathrm{~b}$ \\
PT60+SZ141 & 1.0 & $2.0 \mathrm{~b}$ \\
PT42+SZ141 & 0.9 & $11.9 \mathrm{a}$ \\
PT42+B125 & 1.0 & $0.9 \mathrm{~b}$ \\
\hline
\end{tabular}

Although, the results of the preliminary tests were promising, the chosen bacteria and their combinations failed to improve yield and to protect the plants in the greenhouse and field experiments. It seems that the compositions of bacteria were not proper. There could be several reasons: (i) probably the concentration of the bacteria in the rhizosphere of tomato plants was too low to compete with indigenous microorganisms and to act in natural conditions; (ii) although the bacterial strains were active PGPR, they were not compatible in combinations or their density in the mixtures was not sufficient to act effectively; (iii) the density of $F$. oxysporum $\mathrm{f}$. sp. lycopersici in the infested potting 
medium was too high to be suppressed, while in field conditions the pressure of the pathogens was too low to get any positive effect of bacteria. The concentration of biocontrol agent in the inoculum and in the rhizosphere of treated plants is a crucial factor to obtain a satisfactory effect (Weller 1988). Usually, populations of introduced microorganisms decline in time (Van Veen et al. 1997). This decrease could be faster if the strains in the mixture are not compatible and suppress each other. According to our observations only strain SZ141 was able to suppress isolates of bacteria B125 and PT60 in in vitro tests. Moreover, despite the total concentration of the cells in combined inoculum was the same as in the case of the inoculum prepared of separate strains, the density of the individual strains in the mixture was two times lower, because half volumes of each suspension was used. Such "dillution" could also affect the suppressive properties of mixed inocula. Perhaps, different composition of the bacteria in the mixtures and modification of the application method resulting in increased colonization of root zone of treated plants may lead to enhance the protective effect. Especially, in the case of the mixture B125+PT42, that indicated positive tendency to improve plant growth.

\section{CONCLUSIONS}

1. Treating of tomato seeds with PGPR bacteria and especially with the mixtures of bacteria B125+PT42 and PT42+SZ141 significantly decreased Rhizoctonia damping-off.

2. Bacterization of tomato roots mostly reduced the density of Fusarium spp. in the rhizosphere. However, the density of the pathogen was still high enough to develop disease in sensitive plants $\mathrm{cv}$. Remiz $\mathrm{F}_{1}$.

3. Treatment of tomato plants with selected PGPR bacteria, single strains as well as the combinations of these strains, generally did not affect significantly the growth and yield of tomato plants regardless of their cultivar and the method of cultivation. However, it was found that the mixture of bacteria B125 and PT42 always tended to affect positively the growth of the plants and to reduce their infection by soil-borne pathogens.

\section{REFERENCES}

Bennet A.J., Whips J.M. 2008. Dual application of beneficial microorganisms to seed during priming. Appl. Soil Ecol. 38: 83-89. [DOI: 10.1016/j.apsoil.2007.08.001]

De Boer M., van der Sluis I., van Loon L.C. 1999. Combining fluorescent Pseudomonas spp. strains to enhance suppression of fusarium wilt of radish. Europ. J. Plant Pathol. 105: 201-210.

De Boer M., Bom P., Kindt F., Keurentjes J.J.B., van der Sluis I., van Loon L.C., Bakker P.A.H.M. 2003. Control of fusarium wilt of radish by combining Pseudomonas putida strains that have different disease suppressive mechanisms. Phytopathol. 93: 626-632.

Dhingra O.D., Sinclair J.B. 1995. Basic plant pathology method. Lewis Pub., London: 369.

Fukui R., Fukui H., Alvarez A.M. 1999. Comparisons of single versus multiple bacterial species on biological control of anthurium blight. Phytopathol. 89: 366-373. 
Guetsky R., Shtienberg D., Elad Y., Dinoor A. 2001. Combining biocontrol agents to reduce the variability of biological control. Phytopathol. 91: 621-627.

Guetsky R., Shtienberg D., Elad Y., Fisher E., Dinoor A. 2002. Improving biological control by combining biocontrol agents each with several mechanisms of disease suppression. Phytopathol. 92: 976-985.

Jetiyanon K., Kloepper J.W. 2002. Mixtures of plant growth-promoting rhizobacteria for induction of systemic resistance against multiple plant diseases. Biol. Contr. 24: 285-291.

Park C.S., Paulitz T.C., Baker R. 1988. Biocontrol of Fusarium wilt of cucumber resulting from interactions between Pseudomonas putida and nonpathogenic isolates of Fusarium oxysporum. Phytopathol. 78: 190-194.

Rapauch G.S., Kloepper J.W. 1998. Mixtures of plant growth-promoting rhizobacteria enhance biological control of multiple cucumber pathogens. Phytopathol. 88: 1158-1164.

Spadaro D., Gullino M.L. 2005. Improving efficacy of biocontrol agents against soilborne pathogens. Crop Protect. 24: 601-613. [DOI: 10.1016/j.cropro.2004.11.003]

Szczech M. 2008. Mixtures of microorganisms in biocontrol. In: Progress in Environmental Microbiology. (M.B. Kim ed.). Nova Sc. Pub. INC: 69-110.

Szczech M., Dyki B. 2007. Combination of microbial biocontrol agents to control damping-off and fusarium wilt of tomato. IOBC/WPRS Bull. 30: 415-418.

Szczech M., Shoda M. 2004. Biocontrol of Rhizoctonia damping-off of tomato by $\mathrm{Ba}$ cillus subtilis combined with Burkholderia cepacia. J. Phytopathol. 152: 549-556.

Van Veen J.A., Van Overbeek L.S., Van Elsas D.J., 1997. Fate and activity of microorganisms introduced into soil. Microbiol. Mol. Biol. Rev. 61: 121-135.

Weller D.M. 1988. Biological of soilborne plant pathogens in the rhizosphere with bacteria. Annu. Rev. Phytopathol. 26: 379-407.

\section{MOŻLIWOŚĆ WYKORZYSTANIA WYBRANYCH MIESZANEK BAKTERII PGPR W UPRAWIE POMIDORA}

\section{Streszczenie}

Mieszanki aktywnych bakterii użyto w biologicznej ochronie roślin pomidora przed grzybowymi patogenami pochodzenia glebowego. Ochronne działanie bakterii wstępnie było badane w teście płytkowym wobec Rhizoctonia solani - sprawcy zgorzeli siewek. Najlepsze izolaty oraz ich mieszanki wybrano do doświadczeń uprawowych, prowadzonych w latach 2006-2007 równolegle w warunkach szklarniowych i polowych. Zawiesinami pojedynczych szczepów bakterii lub ich mieszankami inokulowano nasiona, a następnie korzenie rozsady pomidora. W doświadczeniu szklarniowym rośliny wysadzano do podłoża skażonego grzybem patogenicznym Fusarium oxysporum f. sp. lycopersici, a po zakończeniu zbiorów badano zagęszczenie Fusarium sp. w ryzosferze inokulowanych roślin. W doświadczeniu polowym rośliny wysadzano do gleby naturalnie skażonej patogenami. We wszystkich doświadczeniach badano wpływ bakterii na zdrowotność roślin oraz plonowanie. Chociaż wyniki testów płytkowych były obiecujące i wyselekcjonowano szczepy bakterii B125, PT42 i SZ141 oraz ich mieszanki, które skutecznie ograniczały porażenie siewek, w doświadczeniach wegetacyjnych szczepienie roślin wybranymi bakteriami w wielu przypadkach nie dało pozytywnych rezultatów. Jedynie mieszanka szczepów B125 i PT42 wykazywała tendencje do stymulacji wzrostu roślin oraz redukcji ich infekcji przez patogeny. Wykazano jednak, iż w wyniku inokulacji bakteriami nastapiła istotna redukcja zagęszczenia grzybów z rodzaju Fusarium na korzeniach roślin. 